\title{
Investigating the Winemaking Potential of Enchantment, a New Vitis Hybrid Teinturier Cultivar
}

\author{
Sarah E. Mayfield, ${ }^{1}$ Renee T. Threlfall, ${ }^{1 *}$ Dorothea Leis, ${ }^{2}$ Luke R. Howard, ${ }^{1}$ \\ Erich Leitner, ${ }^{2}$ and John R. Clark ${ }^{3}$
}

\begin{abstract}
Enchantment is a Vitis hybrid released from the University of Arkansas System Division of Agriculture winegrape breeding program in 2016. This new teinturier cultivar has potential for producing high-quality wines. The effects of oak addition (no oak, American oak, or French oak) and aging on Enchantment wine attributes were evaluated in 2017 and 2018. Enchantment grapes were harvested in August of both years for wine production. The 2017 and 2018 wines were analyzed initially ( 0 months) for basic chemistry, anthocyanin, color, and aroma attributes, and 2017 wines were analyzed during storage $\left(0,6\right.$, and 12 months at $\left.15^{\circ} \mathrm{C}\right)$ for basic chemistry, anthocyanin, and color attributes. Regardless of oak additions, the initial chemistry of wines in both years was typical for dry wines and remained stable during storage. In both years, malvidin-3-glucoside was the predominant anthocyanin in Enchantment wine, and malvidin-3-glucoside, petunidin-3-glucoside, and delphinidin-3-glucoside comprised $>80 \%$ of total anthocyanin content. Although anthocyanins decreased during storage, the deep red color of the wine remained stable. In 2018, wines had a deeper, darker red color than in 2017; this corresponded with higher anthocyanin levels in 2018. About 50 volatile aroma compounds were identified in Enchantment wines. There was minimal impact of oak treatment on basic chemistry and anthocyanins, but some impact on color attributes. Oak addition greatly impacted aroma attributes, resulting in wines with oaky, roasted, and caramelized aroma compounds in both years. These results demonstrated the potential of Enchantment winegrapes for producing deeply red-colored, single-varietal wines and blends with oaking and storage potential.
\end{abstract}

Key words: anthocyanins, color, oak, teinturier, volatile aroma compounds

Vitis vinifera grapevines are highly vulnerable to pests, diseases, and extreme temperatures and are difficult to grow in much of the United States. Hybrids (crosses of two or more Vitis species) are generally better adapted to surviving stresses that devastate $V$. vinifera grapes (Reisch et al. 2012). The University of Arkansas System Division of Agriculture (UA System) has a fruit-breeding program that was established in 1964. This program began breeding winegrapes over 40 years

\footnotetext{
${ }^{1}$ Department of Food Science, University of Arkansas, 2650 N. Young Ave., Fayetteville, AR 72704; ${ }^{2}$ Institute of Analytical Chemistry and Food Chemistry, Graz University of Technology, Streymayrgasse 9, 8010 Graz, Austria; and ${ }^{3}$ Department of Horticulture, University of Arkansas, 316 Plant Sciences Building, Fayetteville, AR 72701.

*Corresponding author (rthrelf@uark.edu; tel: 479-575-4677; fax: 479-5756936)

Acknowledgments: This research was funded by a Southern Region Small Fruit Consortium (SRSFC) grant (R-16 0403-82467). The authors would also like to acknowledge the staff at the University of Arkansas System Division of Agriculture Fruit Research Station (Clarksville, AR) and the Institute of Analytical Chemistry and Food Chemistry, Graz University of Technology (Graz, Austria) for their assistance with this project.

Supplemental data is freely available with the online version of this article at www.ajevonline.org.

Manuscript submitted Aug 2020, revised Nov 2020, Jan 2021, accepted Jan 2021

This is an open access article distributed under the CC BY license (https:// creativecommons.org/licenses/by/4.0/).

By downloading and/or receiving this article, you agree to the Disclaimer of Warranties and Liability. The full statement of the Disclaimers is available at http://www.ajevonline.org/content/proprietary-rights-notice-ajev-online. If you do not agree to the Disclaimers, do not download and/or accept this article. doi: 10.5344/ajev.2021.20052
}

ago, with a goal of developing new hybrid winegrape cultivars that grow well in Arkansas and similar regions, have unique and desirable attributes, and are suitable for winemaking. In 2016, the first hybrid winegrape cultivars, Opportunity (a white wine cultivar) and Enchantment (a red wine cultivar) were released from the UA System.

The Enchantment grapevine produces teinturier berries with a dark purple color in the skin, flesh, and juice of the grape and shows potential for regions with limited productivity of red wine cultivars. The breeding background and plant, grape, and wine attributes of Enchantment have been determined (Clark et al. 2018). The female parent of Enchantment, Ark. 1628, was a cross between $V$. vinifera cultivars Petite Sirah and Alicante Bouschet. The male parent, Ark. 1481, was a cross between $V$. vinifera-derived cultivars Bouschet Petite and Salvador. Alicante Bouschet, Bouschet Petite, and Salvador are also teinturier cultivars. In evaluations from 1998 to 2015, Enchantment grapevines displayed hardiness for growth in the Arkansas climate, the potential to withstand disease pressures in the region, acceptable fruit yield for commercial production, and berries with good composition for winemaking. Wines have been produced from Enchantment grapes at the UA System Department of Food Science since 1998 using small-scale winemaking techniques. In these preliminary trials, wines showed a deep red color and acceptable composition for a red table wine.

The primary anthocyanin in Enchantment grapes and wine was malvidin-3-glucoside, which is also the primary anthocyanin in $V$. vinifera cultivars (Clark et al. 2018). Malvidin-3-glucoside and other monoglucoside anthocyanins 
are more stable than the diglucoside anthocyanins typically found in hybrid grapes and wine (Cheynier et al. 2006, He et al. 2012, Zhu et al. 2012). Although the color of young red wine is due to monomeric flavylium anthocyanins and their associated copigment complexes, the color contribution from monomeric anthocyanins decreases over time (de Freitas et al. 2017). During aging, anthocyanins participate in three major reactions that can influence wine color: direct polymerization between anthocyanins and tannins, indirect polymerization between anthocyanins and tannins via acetaldehyde, and formation of pyranoanthocyanins ( $\mathrm{Li}$ and Duan 2019). These reactions create compounds/adducts that are more resistant to hydration and bisulfite bleaching and less sensitive to degradation. Therefore, such "polymeric pigments" are important for color in aged red wines (Escribano-Bailón and Santos-Buelga 2012, de Freitas et al. 2017). Unlike monoglucoside anthocyanins, diglucoside anthocyanins are unable to form such polymeric pigments and thus tend to produce wines with less-stable color (Cheynier et al. 2006, He et al. 2012, Zhu et al. 2012). Because of its intense color and vinifera-like anthocyanin composition, Enchantment shows potential to be used in blending to improve wine color quality. Other teinturier cultivars, including Alicante Bouschet, a parent of Enchantment, are commonly used in blending to increase color of wine produced from lightercolored cultivars (Revilla et al. 2016).

In sensory evaluations, Enchantment wines were described as having a fruity aroma similar to that of Syrah and some vegetal characteristics (Clark et al. 2018). It was proposed that Enchantment wines could benefit from addition of oak during wine production. Aging wine in contact with oak can increase complexity through extraction of woody, smoky, spicy, and vanilla aromas (Singleton 1995, Alencar et al. 2019). Oak staves and chips can be used as alternatives to oak barrels, as they are less expensive and more suitable for production of smaller volumes. These "barrel alternatives" can give wines similar complexity and aromatic character as barrel aging (Eiriz et al. 2007). The impact of barrel alternatives (oak powder, shavings, or cubes) on sensory attributes of red wines aged in stainless steel tanks has been evaluated (Cano-López et al. 2008). In general, oak aging improved wine quality and increased fruity, vanilla, woody, spicy, and smoky aromas. Panelists could distinguish between control wines and wines with oak shavings or cubes, and wines aged with oak shavings had the best overall aroma quality. American oak (Quercus alba) and French oak (Quercus robur and Quercus petraea) are the species most commonly used for wine production (Singleton 1995). American oak typically has higher concentrations of oak lactones and possesses more noticeable woody character than French oak (Masson et al. 1995). The impact of American and French oak chips on Syrah wine sensory attributes has been evaluated (Alencar et al. 2019). Wines produced with American oak had more woody characteristics, while wines produced with French oak had more vanilla characteristics.

While the most noticeable effect of maturing wine in contact with oak is the extraction of aroma compounds, oak con- tact can also impact wine pigments and color ( $\mathrm{Li}$ and Duan 2019). The primary non-volatile components extracted into wine from oak are ellagitannins. Oak ellagitannins interact with wine anthocyanins to produce purple-colored ellagitannin-anthocyanin complexes, which were proposed to cause a red-to-purple shift during oak aging (Chassaing et al. 2010). Ellagitannins can be degraded and hydrolyzed to ellagic acid, which can enhance wine copigmentation and protect phenolic compounds from oxidation (Cadahía et al. 2001, Jordão et al. 2006, Zhang et al. 2017). In addition, certain volatile compounds extracted into wine from oak can react with wine phenolics to produce pigment complexes that alter wine color. This could include the brick-red oaklin pigments from oak cinnamic aldehydes and wine flavanols (de Freitas et al. 2004, Sousa et al. 2012) and the orange-red pyranoanthocyanins from oak 4-vinylguaiacol and wine anthocyanins (Fulcrand et al. 1996, Schwarz et al. 2003). Multiple studies evaluated the impact of oak barrel aging and barrel alternatives on wine color, measured through spectrophotometric techniques. Red wines aged with barrel alternatives had greater yellow-tored color ratios than wines aged in traditional oak barrels, while wines aged with French oak had more yellow color than American-oaked wines (del Álamo Sanza et al. 2004). In general, relative to unoaked wines, wine lost color, particularly the red color component, due to oak aging, while the yellow color component increased. Similarly, there was a decrease in red color and an increase in yellow color of red wines with increasing barrel aging times (del Alamo et al. 2000). Although these studies showed a loss in color quality of red wines due to oak aging, sensory studies showed that these color differences were not perceivable (Cano-López et al. 2008, Alencar et al. 2019).

Although Enchantment grapes and wine have been preliminarily evaluated in viticultural and winemaking trials for $>20$ years, there is no published research on the impact of winemaking techniques, such as oak additions, on wine attributes. Since Enchantment grows well in Arkansas and similar regions, the objective of this study was to investigate the winemaking potential of Enchantment, a Vitis hybrid teinturier cultivar.

\section{Materials and Methods}

Grape harvest. Enchantment grapes were grown in an experimental vineyard at the UA System Fruit Research Station in Clarksville, AR (USDA hardiness zone 7b) in the Ozark Mountain American Viticultural Area. The soil type was Linker fine sandy loam (fine-loamy, siliceous, semi-active, thermic Typic Hapludult). The grapes were grown on a highwire bilateral cordon system on own-rooted, variable-aged vines. Average daily temperature and rainfall from January to August in 2017 and 2018 were recorded in Clarksville, AR. About $50 \mathrm{~kg}$ of Enchantment winegrapes were hand-harvested from 10 vines in August 2017 and 2018 for small-scale $(\sim 23 \mathrm{~L})$ wine production. Harvest date was determined based on ideal composition attributes for Arkansas red wine grapes, past harvest data, weather, and fruit quality. The grapes were taken to the UA System Food Science Department 
in Fayetteville, AR and stored at $4^{\circ} \mathrm{C}$ overnight for wine production the following day.

Wine production. In 2017 and 2018, Enchantment wines were produced in a traditional red wine style prior to oak addition and bottling. A single batch of wine was produced each year and was split later for oak treatments in duplicate. Winemaking procedures were kept as similar as possible for both years. Grapes were crushed/destemmed and $30 \mathrm{mg} / \mathrm{L}$ sulfur dioxide $\left(\mathrm{SO}_{2}\right)$ as potassium metabisulfite was added at crush. In 2017, grapes were harvested on 17 Aug and had $14.6 \%$ soluble solids (SS), $\mathrm{pH} 3.14$, and $0.84 \% \mathrm{w} / \mathrm{v}$ (g tartaric acid/100 mL juice) titratable acidity (TA). In 2018, grapes were harvested on 8 Aug and had $17.3 \% \mathrm{SS}, \mathrm{pH} 3.81$, and $0.70 \%$ TA. The SS (expressed as \%) of the must was determined using a Bausch \& Lomb Abbe Mark II refractometer (Scientific Instruments) and the $\mathrm{pH}$ and TA of musts were measured using a Metrohm 862 Compact Titrosampler (Metrohm AG) fitted with a $\mathrm{pH}$ meter. Adjustments were made to the musts to ensure complete fermentation. Must SS was adjusted to $21 \%$ using table sugar (sucrose) in both years, and in 2018 , must TA was adjusted through tartaric acid additions to $0.9 \%$ to reduce the $\mathrm{pH}$ below 3.6 for fermentation.

Musts were inoculated with Lalvin ICV D254 wine yeast (Lallemand, Inc.) at a rate of $0.26 \mathrm{~g} / \mathrm{L}$ and fermented on the skins for four days at $15^{\circ} \mathrm{C}$. At the onset of fermentation, 20 $\mathrm{g} / \mathrm{hL}$ Fermaid $\mathrm{O}$ yeast nutrient (Lallemand, Inc.) was added to musts. Four days of skin contact time was used for this study based on previous winemaking experience with Enchantment. This allowed extraction of compounds from skins without over-extracting tannins and phenolics. After four days, musts were pressed with a 70-L Enoagricola Rossi Hydropress using three 10-min press cycles and a pressure of $207 \mathrm{kPa}$. The wine was collected in a 22.7-L glass carboy fitted with a fermentation lock. Fermentation continued at $15^{\circ} \mathrm{C}$ for approximately six months. Wines were racked several times during fermentation. After fermentation was complete, the free $\mathrm{SO}_{2}$ content of wines was determined using the aerationoxidation method (Iland et al. 1993) and adjusted to $60 \mathrm{mg} / \mathrm{L}$. No further additions of tartaric acid were needed since the $\mathrm{pH}$ of the wine was below 3.6.

The wine was split into six 3.8-L glass jars for oak treatment, with two replications for each treatment. The oak additions included a control (no oak), French oak, and American oak. Medium-toast French oak and American oak staves (38.3 $\times 1.5 \times 1.5 \mathrm{~cm}$; Innerstave, LLC) were placed in the wines and wines were aged on oak for two months at $15^{\circ} \mathrm{C}$. Prior to bottling, free $\mathrm{SO}_{2}$ levels were again measured and adjusted to $60 \mathrm{mg} / \mathrm{L}$. Wines were bottled into $125-\mathrm{mL}$ glass bottles, sealed with plastisol-lined lug caps, and stored at $15^{\circ} \mathrm{C}$ until analysis. Wines were stored at $15^{\circ} \mathrm{C}$ for one week prior to the initial (month 0 ) analysis to account for any bottle shock effects.

In 2017 and 2018, wines were analyzed at 0 months storage for basic chemistry, anthocyanin, color, and aroma attributes. The 2017 wines were analyzed for basic chemistry, anthocyanin, and color attributes after 0,6 , and 12 months storage at $15^{\circ} \mathrm{C}$. Basic chemistry attributes of wines included $\mathrm{pH}, \mathrm{TA}$, glycerol, ethanol, individual and total residual sugars, and individual and total organic acids. Anthocyanin attributes included individual and total anthocyanins. Color attributes included $\mathrm{L}^{*}, \mathrm{a}^{*}, \mathrm{~b}^{*}$, red color (abs $520 \mathrm{~nm}$ ), yellow/brown color (abs $420 \mathrm{~nm}$ ), and color density (abs $520 \mathrm{~nm}+$ abs 420 $\mathrm{nm}$ ). Basic chemistry, anthocyanin, and color attributes for each sample were analyzed in duplicate. Aroma attributes included identification of volatile compounds and determination of relative peak areas. Aroma attributes for each sample were analyzed in triplicate. The composition, anthocyanin, and color attributes were evaluated at the UA System Food Science Department (Fayetteville, AR), and the aroma attributes were evaluated at the Graz Technical University Institute of Analytical Chemistry and Food Chemistry (Graz, Austria).

Composition attributes analysis. $p H$ and $T A$. The $\mathrm{pH}$ and TA of Enchantment wines were measured using a Metrohm 862 Compact Titrosampler fitted with a $\mathrm{pH}$ meter. The probe was left in samples for 2 min to equilibrate before recording the $\mathrm{pH}$ value. The TA was expressed as \% w/v $(\mathrm{g} / 100 \mathrm{~mL})$ tartaric acid. Six grams of sample was weighed, then $50 \mathrm{~mL}$ degassed, deionized water was added to the sample, and the sample was titrated with $0.1 \mathrm{~N}$ sodium hydroxide to an endpoint of $\mathrm{pH}$ 8.2. Wine was degassed prior to analysis.

Glycerol, ethanol, residual sugars, and organic acids. The glycerol, ethanol, residual sugars, and organic acids in Enchantment wines were identified and quantified by highperformance liquid chromatography (HPLC) as described (Walker et al. 2003). Samples were passed through a $0.45 \mu \mathrm{m}$ polytetrafluoroethylene (PTFE) syringe filter (Varian, Inc.) before injection onto an HPLC system consisting of a Waters 515 HPLC pump, a Waters 717 plus autosampler, and a Waters 410 differential refractometer detector connected in series with a Waters 996 photodiode array (PDA) detector (Water Corporation). Analytes were separated with a Bio-Rad HPLC Organic Acids Analysis Aminex HPX-87H ion exclusion column (300 $\times 7.8 \mathrm{~mm}$ ) connected in series with a Bio-Rad HPLC column for fermentation monitoring $(150 \times 7.8 \mathrm{~mm}$; Bio-Rad Laboratories). A Bio-Rad Micro-Guard Cation-H refill cartridge $(30 \times 4.5 \mathrm{~mm})$ was used as a guard column. Columns were maintained at a temperature of $65 \pm 0.1^{\circ} \mathrm{C}$ by a temperature control unit. The isocratic mobile phase consisted of aqueous sulfuric acid at $\mathrm{pH} 2.28$ at a flow rate of $0.45 \mathrm{~mL} / \mathrm{min}$. Injection volumes of both $10 \mu \mathrm{L}$ (for analysis of organic acids and sugars) and $5 \mu \mathrm{L}$ (for ethanol and glycerol) were used to avoid overloading the detector. The total run time per sample was $60 \mathrm{~min}$. Citric, tartaric, malic, lactic, and succinic acids were detected at $210 \mathrm{~nm}$ using the PDA detector, and glucose, fructose, ethanol, and glycerol were detected at $410 \mathrm{~nm}$ using the differential refractometer detector.

Analytes in samples were identified and quantified using external calibration curves based on peak area estimation with baseline integration. Results were expressed as mg analyte/100 mL wine for organic acids and sugars, $\mathrm{g} / \mathrm{L}$ wine for glycerol, and \% v/v for ethanol. Total residual sugars was calculated as the sum of glucose and fructose, and total organic acids was calculated as the sum of tartaric, malic, lactic, citric, and succinic acids. 
Anthocyanin attributes analysis. Anthocyanin quantification. Anthocyanins in Enchantment wines were quantified using the HPLC-PDA as described (Cho et al. 2004). Samples were passed through a $0.45 \mu \mathrm{m}$ PTFE syringe filter before injection onto a Waters Alliance HPLC system equipped with a Waters model 996 PDA detector and Millennium version 3.2 software. A $4.6 \times 250 \mathrm{~mm}$ Symmetry $\mathrm{C}_{18}$ column (Waters Corporation) preceded by a $3.9 \mathrm{~mm} \times 20 \mathrm{~mm}$ Symmetry $\mathrm{C}_{18}$ guard column was used to separate analytes. The mobile phase consisted of a binary gradient with $5 \%(\mathrm{v} / \mathrm{v})$ formic acid in water (solvent $\mathrm{A}$ ) and methanol (solvent B) at a flow rate of $1.0 \mathrm{~mL} / \mathrm{min}$. A gradient was used with 2 to $60 \% \mathrm{~B}$ from 0 to $60 \mathrm{~min}, 60$ to $2 \% \mathrm{~B}$ from 60 to $65 \mathrm{~min}$, then holding at $2 \% \mathrm{~B}$ from 65 to $80 \mathrm{~min}$. A $50 \mu \mathrm{L}$ injection volume was used and total run time per sample was $80 \mathrm{~min}$. Anthocyanins were detected at $510 \mathrm{~nm}$.

Anthocyanins were quantified as anthocyanidin-3-glucoside equivalents of their major aglycone (cyanidin, delphinidin, peonidin, petunidin, or malvidin) using external calibration curves based on peak area estimation with baseline integration. Results were expressed as $\mathrm{mg} / 100 \mathrm{~mL}$ wine. Total anthocyanins were determined by summing concentrations of individual anthocyanin compounds.

Anthocyanin identification. Anthocyanins in Enchantment wines were identified by HPLC-electrospray ionization (ESI)mass spectrometry (MS) as described (Cho et al. 2004). An HPLC-ESI-MS system equipped with an analytical Hewlett Packard 1100 series HPLC instrument (Hewlett-Packard Enterprise Company), an autosampler, a binary HPLC pump, and a UV-vis detector interfaced to a Bruker Esquire LC/ MS ion trap mass spectrometer (Bruker Corporation) was used to identify anthocyanins. Reverse-phase separation of anthocyanins was conducted using the same HPLC conditions previously described for anthocyanin quantification, and absorption was recorded at $510 \mathrm{~nm}$. Mass spectral analysis was operated in positive ion electrospray mode with a capillary voltage of $4000 \mathrm{~V}$, a nebulizing pressure of $30.0 \mathrm{psi}$, a drying gas flow of $9.0 \mathrm{~mL} / \mathrm{min}$, and a temperature of $300^{\circ} \mathrm{C}$. Data was collected with Bruker software in full scan mode over a range of $\mathrm{m} / \mathrm{z} 50$ to 1000 at $1.0 \mathrm{sec}$ per cycle. Characteristic ions were used for peak assignment.

Color attribute analysis. $L^{*}, a^{*}$, and $b^{*}$. Enchantment wine $\mathrm{L}^{*}, \mathrm{a}^{*}$, and $\mathrm{b}^{*}$ color analysis was conducted using a ColorFlex system (HunterLab). This system has a ring and disk set (to control liquid levels and light interactions) for measuring translucent liquids in a $63.5-\mathrm{mm}$ glass sample cup with an opaque cover to determine CIE Lab transmission values of $\mathrm{L}^{*}$, $\mathrm{a}^{*}$, and $\mathrm{b}^{*}$ (Commission Internationale de l'Eclairage 1986). The vertical axis $L^{*}$ measured lightness from completely opaque (0) to completely transparent (100), while the huecircle measured $+a^{*}$ red, $-a^{*}$ green, $+b^{*}$ yellow, and $-b^{*}$ blue.

Red color, yellow/brown color, and color density. Red color of Enchantment wines was measured spectrophotometrically as absorbance at $520 \mathrm{~nm}$, and yellow/brown color was measured as absorbance at $420 \mathrm{~nm}$. Color density was calculated as red color + yellow/brown color (Iland et al. 1993). Absorbance values were measured using a Hewlett-Packard
8452A Diode Array spectrophotometer equipped with UVVisible ChemStation software (Agilent Technologies, Inc.). Samples were diluted 10 times with deionized water prior to analysis and were measured against a blank sample of deionized water. A $1-\mathrm{cm}$ cell was used for all spectrophotometer measurements.

Aroma attribute analysis. Volatile aroma profiles of the wines were determined using headspace (HS)-solid-phase microextraction (SPME)-gas chromatography (GC)-MS as described (Kraujalyté et al. 2012). Volatile compounds were extracted from $1 \mathrm{~mL}$ wine in a $20-\mathrm{mL}$ glass vial using SPME with a 2-cm stable flex divinylbenzene/carboxen/polydimethylsiloxane (DVB/CAR/PDMS) fiber for $30 \mathrm{~min}$ at $40^{\circ} \mathrm{C}$. The samples were thermostated at $40^{\circ} \mathrm{C}$ for $10 \mathrm{~min}$ before exposing the fiber to enrich the volatiles. A GC-MS system equipped with a Shimadzu GC 2010 (Shimadzu Corporation), Shimadzu QP 2010 MS, and PAL HTX autosampler (CTC Analytics AG) was used to separate and identify volatile compounds. Samples were extracted/injected in triplicate. Volatiles were separated on a nonpolar Restek Rxi 5MS column $(30 \mathrm{~m} \times 0.25 \mathrm{~mm} \times 1 \mu \mathrm{m}$; Restek) with a temperature gradient program: $30^{\circ} \mathrm{C}$ (hold $1 \mathrm{~min}$ ) to $230^{\circ} \mathrm{C}$ at $5^{\circ} \mathrm{C} / \mathrm{min}$, then to $280^{\circ} \mathrm{C}$ (hold $1 \mathrm{~min}$ ) at $20^{\circ} \mathrm{C} / \mathrm{min}$ in constant flow mode with a linear velocity of $35 \mathrm{~cm} / \mathrm{min}$. Data was recorded in the scan mode ( $\mathrm{m} / \mathrm{z} 35$ to 350 ) with a 9.8 min solvent cut time and a detector voltage relative to the tuning result.

Data was analyzed using the Shimadzu GCMS Solution Analysis software (Version 4.45). Compounds were identified using comparison with three mass spectra libraries: National Institute of Standards and Technology (NIST14), Flavors and Fragrances of Natural and Synthetic Compounds (FFNSC3; Mondello 2015), and Adam's Essential Oils (Adams 2007). A series of n-alkanes from C8 to C20 were measured under identical conditions to calculate Kovats retention indices (Kováts 1958) of volatile compounds in wine samples. The identities of compounds were confirmed by comparison of calculated retention indices with values reported in the Flavornet (Acree and Arn 2004) and Pherobase (El-Sayed 2003) databases. A matching library result and a retention index within \pm 20 of previously reported values was considered a positive identification. Total ion chromatogram (TIC) peak areas were used to determine the relative peak areas (\%) for each compound.

Experimental design and statistical analysis. In both years, a single batch of wine was fermented, then split into three oak treatments (no oak, American oak, or French oak) in two replications. Replications were limited in this study because there was not enough fruit to produce more wines while maintaining reasonable fermentation volumes. There were six samples ( 3 oak treatments $\times 2$ replications) when wines were analyzed at 0 months storage, and there were 18 samples ( 3 oak treatments $\times 3$ storage times $\times 2$ replications) in 2017 when wines were analyzed during storage. At each storage time, samples for basic chemistry, anthocyanin, color, and aroma attributes were taken from one $125-\mathrm{mL}$ bottle. Statistical analyses were conducted using JMP Pro statistical software (version 15.0.0, SAS Institute, Inc.). 
Basic chemistry, anthocyanin, and color attributes. For 2017 and 2018 wines at 0-months storage, a univariate analysis of variance (ANOVA) was used to determine the significance of the main factors, year and oak treatment, and their interaction. Tukey's honest significant difference (HSD) was used to detect differences among means $(p<0.05)$. For the 2017 wines during storage, a univariate mixed-model with a first-order autoregressive (AR1) covariance structure was used to conduct a repeated measures in time analysis, with individual experimental units (wines) as the subjects in a repeated structure for storage time. For the fixed effects (storage and oak), an ANOVA was used to determine the significance of the main factors and their interaction. All factors were treated as categorical. Tukey's HSD was used to detect differences among means $(p<0.05)$ for the fixed effects.

Aroma attributes. Relative peak areas (\%) for each positively identified compound in 2017 and 2018 Enchantment wines at 0 -months storage were used for principal components analysis (PCA). Each compound was assigned a chemical compound class and a general aroma category based on aroma descriptors reported in the Flavornet (Acree and Arn 2004) and Pherobase (El-Sayed 2003) databases. The relative peak areas of compounds within each compound class and aroma category were summed to create general variables. This was done so that the model did not overfit to noise, which occurs when the number of parameters is greater than the number of variables. PCAs were conducted based on the compound class and aroma category variables and were used to explore the relationship between oak treatments and volatile aroma profiles.

\section{Results and Discussion}

The 2017 and 2018 winegrape production seasons in Clarksville, AR, were relatively mild in temperature and rainfall. The high and low temperatures were similar from January to August in both years, with more rainfall from April (budbreak on grapevines) to July prior to harvest in 2017 than in 2018. In August of 2017 and 2018, the average daily high temperatures were $28.6^{\circ} \mathrm{C}$ and $30.0^{\circ} \mathrm{C}$, respectively. In August, there was less cumulative monthly rainfall in 2017 $(198.5 \mathrm{~mm})$ than in $2018(281.7 \mathrm{~mm})$.

The grapes were harvested in August of both years for wine production. After about eight months fermentation and two months aging on oak, the wines were bottled in May and stored at $15^{\circ} \mathrm{C}$. In 2017 and 2018 Enchantment wines, the impacts of year and oak addition on all attributes (basic chemistry, anthocyanin, color, and aroma) were evaluated at 0 -months storage. In 2017 Enchantment wines, the basic chemistry, anthocyanin, and color attributes were evaluated after 0,6 , and 12 months storage at $15^{\circ} \mathrm{C}$.

Basic chemistry, anthocyanin, color, and aroma attributes at 0 -months storage (2017 and 2018). The impact of oak treatment on basic chemistry, anthocyanin, color, and aroma attributes was mostly consistent between the two years in which the study was replicated. The year had a major impact on most attributes, while oak addition mainly affected color and aroma attributes.
Basic chemistry attributes. Enchantment wines were analyzed for $\mathrm{pH}$, TA, glycerol, ethanol, glucose, fructose, total residual sugars, tartaric acid, malic acid, citric acid, succinic acid, lactic acid, and total organic acids (Table 1). Of the basic chemistry attributes, the year $\times$ oak interaction was only significant for citric acid. The year impacted all basic chemistry attributes except glycerol and ethanol. The 2018 wines had a lower $\mathrm{pH}$ and higher TA than 2017 wines. Oak treatment was also significant for $\mathrm{pH}$, although there was very little variation in $\mathrm{pH}$ values among oak treatments. Glycerol and ethanol contents of Enchantment wines fell within the ranges of 7 to $10 \mathrm{~g} / \mathrm{L}$ glycerol and 11 to $14 \%$ ethanol reported for dry table wines (Liu and Davis 1994, Alston et al. 2011).

There was no impact of oak treatment on residual sugar concentrations in Enchantment wines. Wines from 2017 had more glucose, fructose, and total residual sugar levels than 2018 wines. The residual sugar levels in all wines were $<1 \%$ and were similar to concentrations of 50 to $100 \mathrm{mg} / 100 \mathrm{~mL}$ glucose and 20 to $400 \mathrm{mg} / 100 \mathrm{~mL}$ fructose reported for dry table wines (Liu and Davis 1994).

Wine from 2017 had higher concentrations of each individual acid and total organic acids than 2018 wines. In the year $\times$ oak interaction, there was no difference among oak treatments for citric acid levels in 2018 wines. In 2017, French-oaked wines had more citric acid than unoaked or American-oaked wines, and 2017 wines had more citric acid than all 2018 wines. In general, concentrations of tartaric, malic, and lactic acids in Enchantment wines were within reported ranges of 200 to $600 \mathrm{mg} / 100 \mathrm{~mL}$ tartaric acid, 200 to $700 \mathrm{mg} / 100 \mathrm{~mL}$ malic acid, and 0 to $300 \mathrm{mg} / 100 \mathrm{~mL}$ lactic acid for dry table wines (Fowles 1992, Sowalsky and Noble 1998, Da Conceicao Neta et al. 2007). However, concentrations of citric and succinic acids were higher than reported ranges of 10 to 70 $\mathrm{mg} / 100 \mathrm{~mL}$ citric acid and 50 to $100 \mathrm{mg} / 100 \mathrm{~mL}$ succinic acid for dry table wines (Fowles 1992, Sowalsky and Noble 1998, Da Conceicao Neta et al. 2007).

Anthocyanin attributes. Enchantment wines were analyzed for individual and total anthocyanins, including the monoglucosides and their acetyl and coumaryl derivatives (Table 2). Of note, only anthocyanin monoglucosides, not their diglucoside counterparts, were detected in Enchantment wines. The native and hybrid wines that typically grow well in Arkansas and the mid-south United States contain significant amounts of diglucoside anthocyanins (Pastrana-Bonilla et al. 2003, Zhu et al. 2012). Unlike monoglucosides, diglucosides do not form copigment and acylated complexes and are therefore more susceptible to bisulfite bleaching or hydration (Cheynier et al. 2006, He et al. 2012, Zhu et al. 2012). In both years, malvidin-3-glucoside was the predominant anthocyanin in Enchantment wines, followed by petunidin-3-glucoside and delphinidin-3-glucoside. While malvidin-3-glucoside was the predominant anthocyanin in young red wines from the teinturier grape Alicante Bouschet, peonidin-3-glucoside was the second-most prevalent, followed by petunidin-3-glucoside (García-Beneytez et al. 2003, Revilla et al. 2016). Alicante Bouschet is a parent of Enchantment, which also had malvidin-3-glucoside as the predominant anthocyanin. 
The concentrations of anthocyanin compounds in Enchantment wines are shown in Supplemental Table 1 and Figure 1. Total anthocyanin levels were similar to the levels of 44 to $164 \mathrm{mg} / 100 \mathrm{~mL}$ reported for young Alicante Bouschet wines (Revilla et al. 2016). Multiple studies have evaluated the anthocyanin profile of Syrah wines. Syrah is a parent of Petite Sirah (Syrah $\times$ Peloursin), and Petite Sirah is a parent of Enchantment (Meredith et al. 1999). Young Spanish Syrah wines had $53 \mathrm{mg} / 100 \mathrm{~mL}, 65 \mathrm{mg} / 100 \mathrm{~mL}$, or 22 $\mathrm{mg} / 100 \mathrm{~mL}$ total anthocyanins, respectively, in three studies (Gómez-Míguez and Heredia 2004, Gutiérrez et al. 2005, or Gómez-Míguez et al. 2007). The lower anthocyanin levels in Syrah wines than in the Enchantment wines in the present study are logical, as Enchantment is a teinturier grape

Table 1 Effect of year (2017 or 2018) and oak treatment (no oak, American oak, or French oak staves) on basic chemistry attributes after 0-months storage of wines produced from Enchantment grapes grown at the University of Arkansas System Division of Agriculture Fruit Research Station, Clarksville, AR.

\begin{tabular}{|c|c|c|c|c|c|c|c|c|c|c|c|c|c|}
\hline Effects & pH & $\begin{array}{l}\text { Titratable } \\
\text { acidity }^{\mathrm{a}} \\
(\%)\end{array}$ & $\begin{array}{c}\text { Glycerol } \\
(\mathbf{g} / \mathrm{L})\end{array}$ & $\begin{array}{l}\text { Ethanol } \\
(\% \mathrm{v} / \mathrm{v})\end{array}$ & $\begin{array}{c}\text { Glucose } \\
\text { (mg/100 } \\
\mathrm{mL})\end{array}$ & $\begin{array}{c}\text { Fructose } \\
\text { (mg/100 } \\
\mathrm{mL})\end{array}$ & $\begin{array}{c}\text { Total } \\
\text { residual } \\
\text { sugars } \\
\text { (mg/100 } \\
\mathrm{mL})\end{array}$ & $\begin{array}{c}\text { Tartaric } \\
\text { acid } \\
(\mathrm{mg} / 100 \\
\mathrm{mL})\end{array}$ & $\begin{array}{c}\text { Malic } \\
\text { acid } \\
(\underset{\mathrm{mg}}{\mathrm{mL}} \mathbf{1 0 0} \\
\mathrm{mL})\end{array}$ & $\begin{array}{c}\text { Citric } \\
\text { acid } \\
(\mathrm{mg} / 100 \\
\mathrm{mL})\end{array}$ & $\begin{array}{c}\text { Succinic } \\
\text { acid } \\
(\mathrm{mg} / 100 \\
\mathrm{mL})\end{array}$ & $\begin{array}{c}\text { Lactic } \\
\text { acid } \\
(\underset{\mathrm{mg} / 100}{\mathrm{~mL})}\end{array}$ & $\begin{array}{c}\text { Total } \\
\text { organic } \\
\text { acids } \\
(\mathrm{mg} / 100 \\
\mathrm{mL})\end{array}$ \\
\hline \multicolumn{14}{|l|}{ Year } \\
\hline 2017 & $3.44 a^{b}$ & $0.62 \mathrm{~b}$ & 7.85 & 11.15 & $53.46 \mathrm{a}$ & $184.93 \mathrm{a}$ & $238.39 \mathrm{a}$ & $580.50 \mathrm{a}$ & $458.96 \mathrm{a}$ & $233.37 \mathrm{a}$ & $715.46 \mathrm{a}$ & $303.41 \mathrm{a}$ & $2291.71 \mathrm{a}$ \\
\hline 2018 & $3.25 \mathrm{~b}$ & $0.70 \mathrm{a}$ & 7.82 & 11.17 & 39.03 b & $100.67 \mathrm{~b}$ & $139.70 \mathrm{~b}$ & $412.92 \mathrm{~b}$ & $218.39 \mathrm{~b}$ & $172.37 \mathrm{~b}$ & $361.74 \mathrm{~b}$ & $95.50 \mathrm{~b}$ & $1260.92 b$ \\
\hline$p$ value & $<0.0001^{c}$ & $<0.0001$ & 0.7732 & 0.8314 & 0.0019 & $<0.0001$ & $<0.0001$ & $<0.0001$ & $<0.0001$ & $<0.0001$ & 0.0002 & 0.0107 & $<0.0001$ \\
\hline \multicolumn{14}{|l|}{ Oak } \\
\hline No oak & $3.34 \mathrm{~b}$ & 0.66 & 7.76 & 11.03 & 41.78 & 124.50 & 166.28 & 478.56 & 351.78 & $192.94 b$ & 573.51 & 245.71 & 1842.50 \\
\hline American oak & $3.35 \mathrm{a}$ & 0.66 & 7.82 & 11.17 & 49.44 & 140.40 & 189.83 & 519.58 & 363.16 & $196.30 \mathrm{~b}$ & 602.90 & 232.29 & 1914.23 \\
\hline French oak & $3.34 a b$ & 0.66 & 7.92 & 11.29 & 47.51 & 163.51 & 211.02 & 492.00 & 301.10 & 219.38 a & 439.38 & 120.35 & 1572.22 \\
\hline$p$ value & 0.0030 & 0.6703 & 0.2557 & 0.1212 & 0.2860 & 0.1469 & 0.1864 & 0.4786 & 0.0995 & 0.0056 & 0.1962 & 0.3287 & 0.3056 \\
\hline \multicolumn{14}{|l|}{ Year x Oak } \\
\hline \multicolumn{14}{|l|}{2017} \\
\hline No oak & 3.44 & 0.62 & 7.78 & 11.01 & 46.84 & 149.80 & 196.64 & 548.89 & 492.52 & $215.51 \mathrm{~b}$ & 782.62 & 391.34 & 2430.87 \\
\hline American oak & 3.44 & 0.62 & 7.83 & 11.12 & 55.44 & 173.53 & 228.97 & 624.08 & 504.26 & $219.48 b$ & 842.57 & 366.67 & 2557.06 \\
\hline French oak & 3.44 & 0.62 & 7.94 & 11.33 & 58.10 & 231.47 & 289.57 & 568.54 & 380.12 & $265.13 \mathrm{a}$ & 521.18 & 152.23 & 1887.19 \\
\hline \multicolumn{14}{|l|}{2018} \\
\hline No oak & 3.24 & 0.70 & 7.75 & 11.05 & 36.73 & 99.20 & 135.92 & 408.22 & 211.04 & $170.38 \mathrm{c}$ & 364.41 & 100.09 & 1254.13 \\
\hline American oak & 3.25 & 0.70 & 7.82 & 11.22 & 43.43 & 107.27 & 150.70 & 415.08 & 222.05 & $173.11 \mathrm{c}$ & 363.23 & 97.92 & 1271.39 \\
\hline French oak & 3.25 & 0.70 & 7.91 & 11.26 & 36.92 & 95.55 & 132.47 & 415.46 & 222.08 & $173.63 \mathrm{c}$ & 357.59 & 88.48 & 1257.25 \\
\hline$p$ value & 0.0751 & 0.8734 & 0.9902 & 0.7842 & 0.4897 & 0.0832 & 0.1164 & 0.5691 & 0.0708 & 0.0106 & 0.2203 & 0.3937 & 0.3234 \\
\hline
\end{tabular}

${ }^{a}$ Expressed as $\% \mathrm{w} / \mathrm{v}(\mathrm{g} / 100 \mathrm{~mL})$ tartaric acid.

${ }^{b}$ Connecting letters are only shown for attributes with significant differences among treatments. Means with different letters for each attribute within effects are significantly different $(p<0.05)$ according to Tukey's honest significant difference test.

${ }^{c} p$ values denoted with bold text are significant $(p<0.05)$.

Table 2 Anthocyanins identified in Enchantment wines after 0-months storage produced from Enchantment grapes grown at the University of Arkansas System Division of Agriculture Fruit Research Station, Clarksville, AR (2017 and 2018).

\begin{tabular}{|c|c|c|c|c|}
\hline \multirow[b]{2}{*}{ Compound } & \multirow{2}{*}{$\begin{array}{l}\text { Molecular ion } \\
(\mathrm{m} / \mathrm{z})\end{array}$} & \multirow{2}{*}{$\begin{array}{l}\text { Characteristic } \\
\text { fragment peak } \\
(\mathrm{m} / \mathrm{z})\end{array}$} & \multicolumn{2}{|c|}{ Relative composition ${ }^{a}(\%)$} \\
\hline & & & 2017 & 2018 \\
\hline Malvidin-3-O-glucoside & 493 & 331 & 45.7 & 37.2 \\
\hline Petunidin-3-O-glucoside & 479 & 317 & 20.4 & 14.8 \\
\hline Delphinidin-3-O-glucoside & 465 & 303 & 14.7 & 11.7 \\
\hline Peonidin-3-O-glucoside & 463 & 301 & 11.9 & 7.1 \\
\hline Cyanidin-3-O-glucoside & 449 & 287 & 1.8 & 0.5 \\
\hline Malvidin-3-O-(6-O-acetyl)-glucoside & 535 & 331 & 0.9 & 8.7 \\
\hline Petunidin-3-O-(6-O-acetyl)-glucoside & 521 & 317 & 0.6 & 3.9 \\
\hline Delphinidin-3-O-(6-O-acetyl)-glucoside & 507 & 303 & 0.8 & 1.7 \\
\hline Peonidin-3-O-(6-O-acetyl)-glucoside & 505 & 301 & 0.2 & 2.1 \\
\hline Cyanidin-3-O-(6-O-acetyl)-glucoside & 491 & 287 & 0.1 & 0.4 \\
\hline Malvidin-3-O-(6-O-p-coumaryl)-glucoside & 639 & 331 & 1.8 & 6.3 \\
\hline Petunidin-3-O-(6-O-p-coumaryl)-glucoside & 625 & 317 & 0.8 & 1.7 \\
\hline Delphinidin-3-O-(6-O-p-coumaryl)-glucoside & 611 & 303 & 0.8 & 1.7 \\
\hline Cyanidin-3-O-(6-O-p-coumaryl)-glucoside & 595 & 287 & 0.2 & 0.3 \\
\hline
\end{tabular}

${ }^{a}$ Average relative composition (\%) across oak treatments (no oak, American oak, or French oak staves). 
and thus produces wines with more anthocyanins and deeper color (Santiago et al. 2008).

The year $\times$ oak interaction was not significant for anthocyanin attributes, but year was significant for all anthocyanin attributes except peonidin-3-glucoside (Figure 1). Enchantment wines from 2018 had higher concentrations of malvidin3-glucoside, petunidin-3-glucoside, delphinidin-3-glucoside, total anthocyanins, total acylated anthocyanins, and total coumaryl anthocyanins, while 2017 wines had higher concentrations of cyanidin-3-glucoside, though levels were low. The generally higher anthocyanin levels in 2018 wines could have been due to the 2018 grapes being riper at harvest, as evidenced by higher SS and $\mathrm{pH}$ values. In addition, environmental factors such as temperature, pests, or rain could have caused the difference in anthocyanin levels between the two years (Kliewer 1977, Spayd et al. 2002).

Oak treatment did not impact anthocyanin levels of Enchantment wines, which contrasted with previous studies. Spanish red wines aged in oak barrels or with oak chips and staves lost monomeric anthocyanins faster in the wines aged with oak alternatives than in wines aged in barrels, and French-oaked wines had slightly more anthocyanins at the end of oak aging than American-oaked wines (del AlamoSanza and Domíngues 2006). Similarly, another study reported lower anthocyanin concentrations in Spanish red wines aged with oak alternatives than in those aged in oak barrels, but found no difference among oak species (del Álamo Sanza et al. 2004).

Color attributes. Enchantment wines were evaluated for $\mathrm{L}^{*}, \mathrm{a}^{*}, \mathrm{~b}^{*}$, red color (abs $520 \mathrm{~nm}$ ), brown/yellow color (abs $420 \mathrm{~nm}$ ), and color density (red color + yellow/brown color) (Supplemental Table 2 and Figure 2). The year $\times$ oak interac-

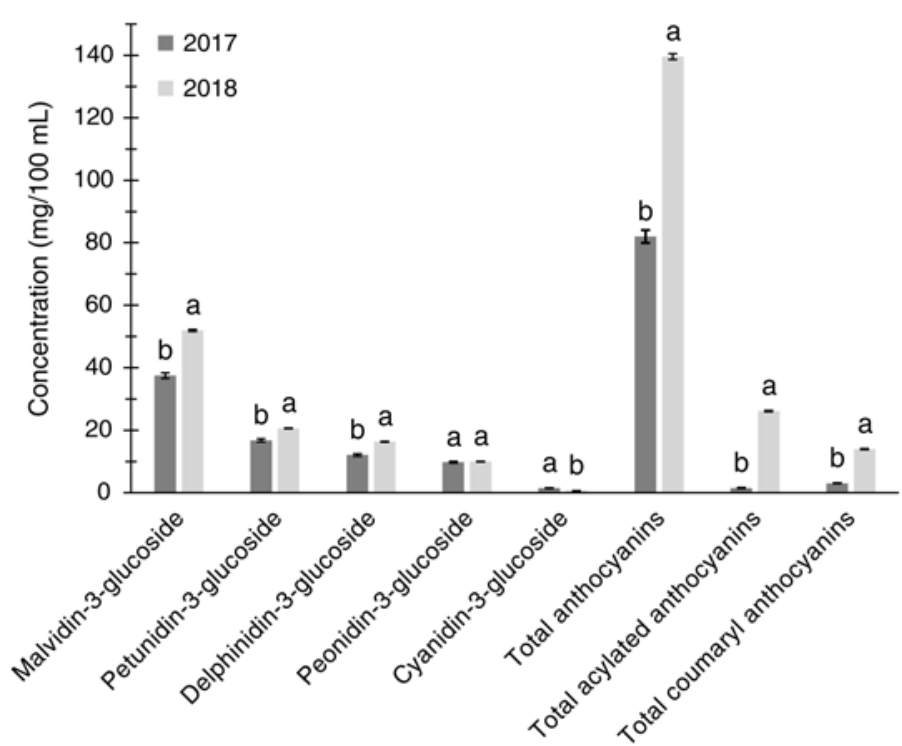

Figure 1 Effect of year (2017 or 2018) on anthocyanin attributes at 0-months storage of wines produced from Enchantment grapes grown at the University of Arkansas System Division of Agriculture Fruit Research Station, Clarksville, AR. Error bars represent standard error. Means with different letters for each attribute are significantly different $(p<0.05)$ according to student's $t$-test. tion was significant for L* (Figure 2A). All 2018 wines had lower L* (darker color) than 2017 wines. In 2018, Frenchoaked wine had a darker color than American-oaked or unoaked wines. There was no difference in $\mathrm{L}^{*}$ among oak treatments in 2017. The year and oak treatment impacted $\mathrm{a}^{*}$ and $b^{*}$. Enchantment wines from 2018 had higher a* (more red color) and higher $\mathrm{b}^{*}$ (more yellow color) than 2017 wines, indicating a greater overall color intensity. French-oaked wines had higher $\mathrm{a}^{*}$ and $\mathrm{b}^{*}$ than unoaked wines, while unoaked wines had higher values than American-oaked wines. This was consistent with results of Alencar et al. (2019), who found that wines aged with French oak chips displayed an $18 \%$ increase in a* over wines with American oak chips and unoaked wines, and a 25 to $29 \%$ increase in $b^{*}$. The year $\times$ oak interaction was also significant for red color (Figure 2B). All 2018 wines had more red color than 2017 wines, but there were no differences among oak treatments within either year. The year main effect was significant for brown/yellow color and color density, and 2018 wines had less brown/yellow color and greater color density than 2017 wines. The increased red color and color density and reduced brown/yellow color of 2018 wines could indicate that these wines had a more desirable color, consistent with their greater anthocyanin levels. The color density values for both 2017 and 2018 Enchantment wines in this study were greater than the average color density of 19.1 reported for young Alicante Bouschet wines (Revilla et al. 2016).

There were only slight differences among oak treatments for color attributes of Enchantment wines. Previous studies
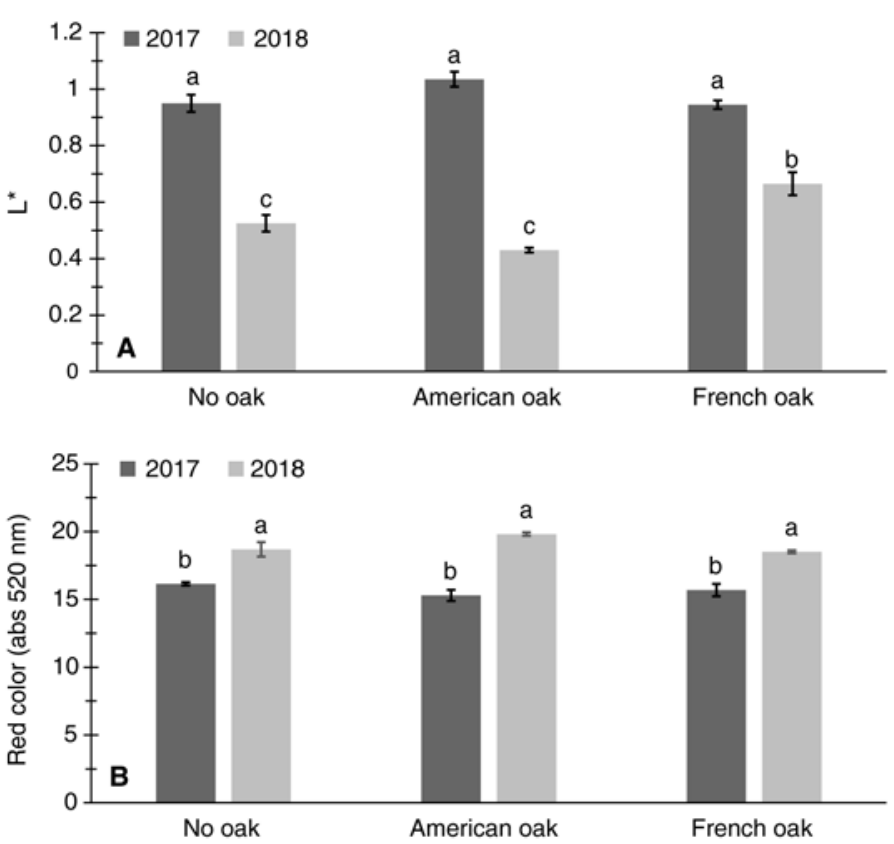

Figure 2 Effect of year (2017 or 2018) and oak treatment (no oak, American oak, or French oak staves) on $\mathrm{L}^{*}(\mathbf{A})$ and red color $(\mathbf{B})$ at 0 -months storage of wines produced from Enchantment grapes grown at the University of Arkansas System Division of Agriculture Fruit Research Station, Clarksville, AR. Error bars represent standard error. Means with different letters for each attribute are significantly different $(p<0.05)$ according to Tukey's honest significant difference test. 
reported an impact of oak exposure on red wine color. French-oaked wines had more yellow color than Americanoaked wines (del Álamo Sanza et al. 2004). This is consistent with higher $b^{*}$ values of French-oaked Enchantment wine in the present study. The impact of oak contact on wine color can depend on species of oak (Jindra and Gallander 1987, Revilla and González-SanJosé 2001). There was an increased yellow-to-red color ratio in wines aged with barrel alternatives, relative to wines aged in traditional oak barrels, thus, barrel alternatives may alter chromatic characteristics of red wine more rapidly than barrels (del Álamo Sanza et al. 2004). However, sensory panelists could not detect a difference in color among red wines aged with barrel alternatives and those aged in oak barrels (Cano-López et al. 2008). Similarly, there was no effect of oak chip addition on perceived color of Syrah wines, despite slight impacts of oak addition on spectrophotometric measurements (Alencar et al. 2019).

Teinturier wines such as Alicante Bouschet are often used in wine blends to increase the color of wines made from lighter-colored cultivars (Revilla et al. 2016). The effects of blending wines with less-desirable color with varieties with more ideal color attributes have been studied (Li et al. 2020). All blended wines had greater color intensity and red color than control wines. As anthocyanin content and color of Enchantment wines were similar to those reported for Alicante Bouschet (Revilla et al. 2016), Enchantment could potentially be used in wine blends to improve color. This would be especially significant for wines produced from grapes grown in the mid-south United States, where Enchantment grapevines have been shown to grow well (Clark et al. 2018). The grape varieties typically produced in this region have less stable anthocyanins than $V$. vinifera grapes and therefore struggle with color loss during aging (Cheynier et al. 2006, He et al. 2012, Zhu et al. 2012).

Multiple studies evaluated the impact of wine blending on wine sensory attributes. García-Carpintero et al. (2010) produced blends from three Spanish red varieties and performed descriptive analysis. All blends were rated higher for desirable sensory attributes and complexity than singlevarietal wines. Similarly, in a study on the effect of blending on perceived complexity of 34 blends of two similar wines, all blends were rated higher than the lower-scoring wine of each pair on its own, and higher ratings were attributed to the increased complexity of blended wines (Singleton and Ough 1962). Adding 10\% of either Graciano or Cabernet Sauvignon to Tempranillo wines made a visually detectable color difference, and blends had higher overall ratings than single-varietal Graciano, Cabernet Sauvignon, or Tempranillo wines (Monagas et al. 2006a, 2006b). Therefore, using Enchantment wine in blends with less-intensely-colored varieties may increase the overall complexity of wines and improve color.

Aroma attributes. Fifty-two volatile aroma compounds were identified in 2017 Enchantment wines, and 50 compounds were identified in 2018 wines (Table 3). Compounds included chemical, floral, fruity, green/fat, roasted/caramelized, and vegetal alcohols; floral, green/fat, and roasted/cara- melized aldehydes; vegetal alkyl sulfides; chemical benzothiazoles; fruity, green/fat, and unpleasant carboxylic acids; floral and fruity esters; chemical ethers; roasted/caramelized furans; fruity glycols; green/fat and vegetal ketones; floral, fruity, and herbal/spicy terpenes; and oaked lactones.

The esters were the largest class of compounds in all wines. Esters are characteristic by-products of alcoholic fermentation and are central aroma compounds in most wines. While some esters, such as ethyl esters, are relatively stable in wines during storage, acetate esters in particular decrease with time (Ramey and Ough 1980, Waterhouse et al. 2016). When Enchantment wines were analyzed for aroma attributes at 0 -months storage, esters were predominant. Oak lactone, an aliphatic $\gamma$-lactone extracted into wine during contact with oak, was only identified in 2017 American-oaked wines, and not in 2017 French-oaked wines or 2018 wines.

PCA was used to reduce the dimensionality of the data and to elucidate relationships among compound classes, aroma categories, and oak treatments. The relative TIC peak areas (\%) were summed for compounds within each compound class and aroma category. The PCAs showed differences in compound classes and aroma categories among oak treatments in 2017 and 2018.

In a PCA of compound class variables (Figure 3A), two components explained $83 \%$ of the variation in the data. PC1 $(69.6 \%)$ had positive loadings for benzothiazoles, alkyl sulfides, glycols, alcohols, terpenes, lactones, aldehydes, furans, and all 2017 wines, regardless of oak treatment. Ethers, esters, ketones, carboxylic acids, and all 2018 wines loaded negatively on PC1. This indicated that there was a difference between 2017 and 2018 wines based on relative abundance of different classes of compounds. It was likely that 2018 wines had more esters. PC2 (13.5\%) had positive loadings for carboxylic acids, terpenes, alcohols, and 2017 and 2018 unoaked wines. Aldehydes, lactones, and 2017 and 2018 American- and Frenchoaked wines loaded negatively on PC2. Therefore, there was a clear separation between oaked and unoaked wines based on compound class variables.

In a PCA of aroma category variables (Figure 3B), two components explained $89 \%$ of the variation in the data. PC1 (66.3\%) had positive loadings for vegetal, chemical, floral, herbal/spicy, roasted/caramelized, unpleasant, and oaked aroma categories, and for all 2017 wines, regardless of oak treatment. Fruity and green/fat aroma categories and all 2018 wines loaded negatively on PC1. This indicated that there was a clear distinction between 2017 and 2018 wines based on the distribution of volatile compounds among different aroma categories. The association of 2018 wines with fruity aromas was consistent with their association with esters in the compound class PCA. Esters are characteristic by-products of yeast during alcoholic fermentation; their production is influenced by factors such as must composition, oxygen availability, and temperature (Waterhouse et al. 2016). Although must composition and fermentation conditions were consistent among years, slight variations in such factors could explain the difference in relative ester content between 2017 and 2018 Enchantment wines. 


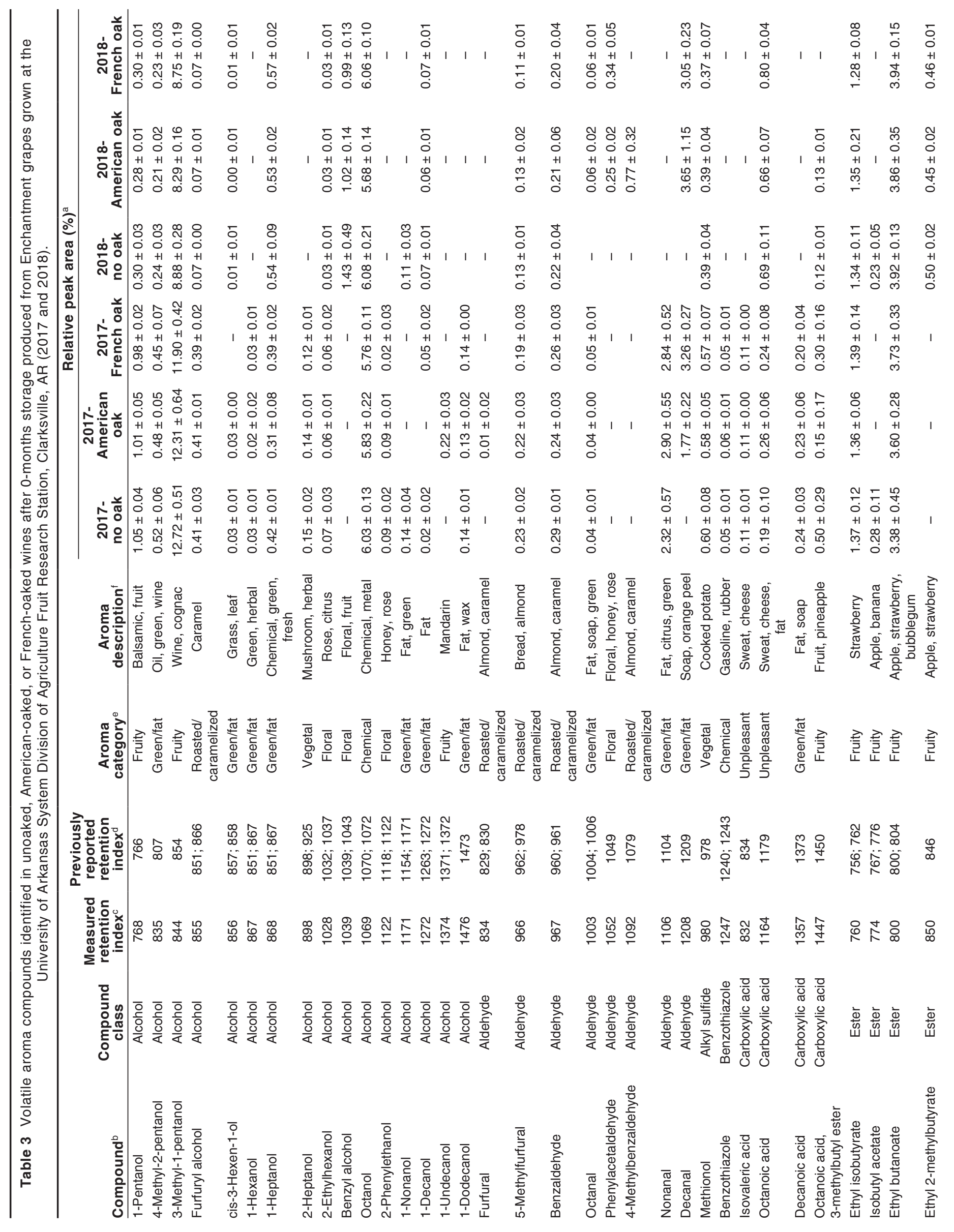



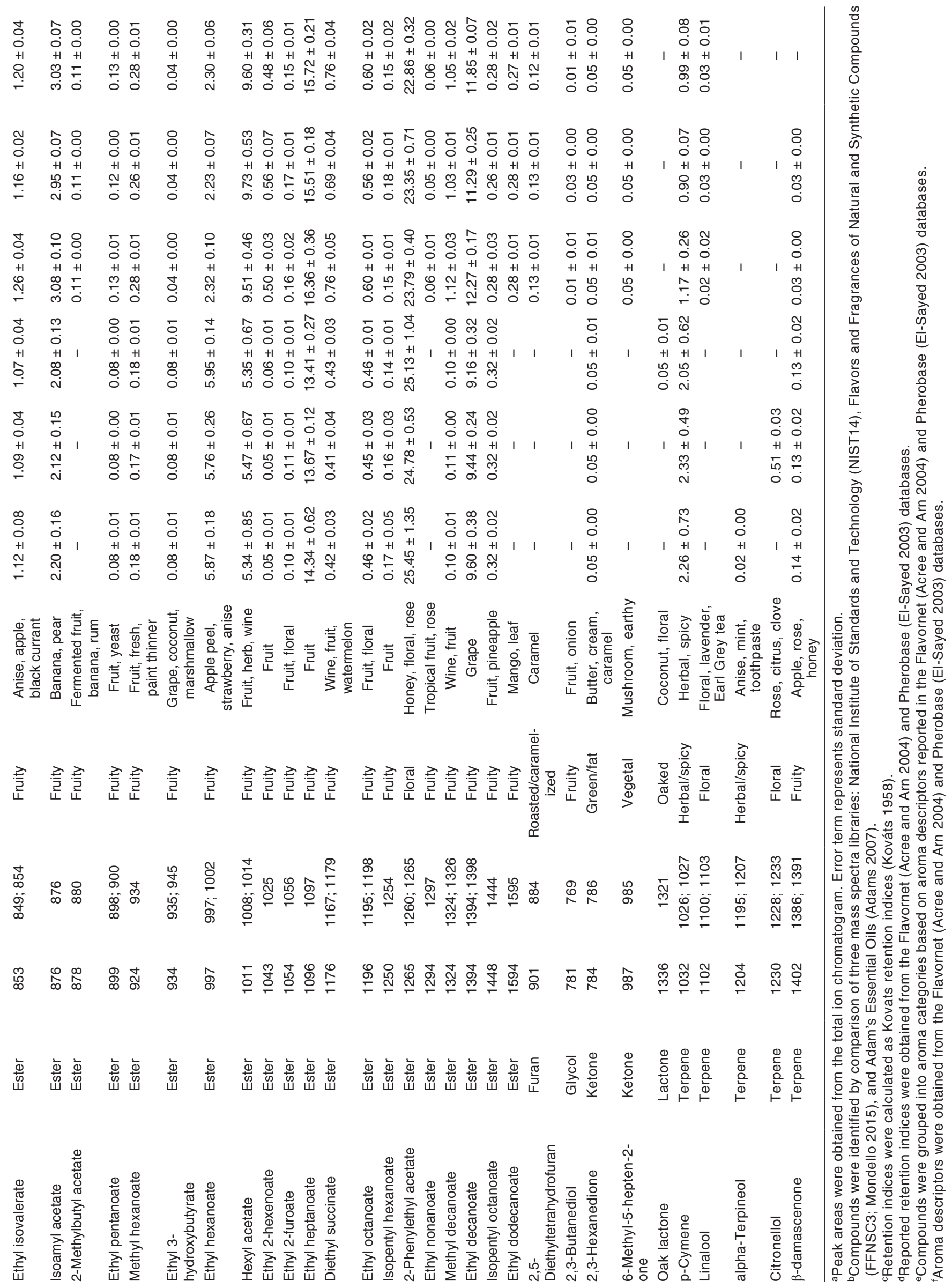
In Figure 3B, PC2 (22.5\%) had positive loadings for unpleasant and herbal/spicy aroma categories and 2017 and 2018 unoaked wines. Roasted/caramelized and oaked aroma categories and 2017 and 2018 American- and French-oaked wines loaded negatively on PC2. The association of unoaked wines with unpleasant and herbal/spicy aromas was consistent with their association with carboxylic acids and terpenes, respectively, in the compound class PCA. The association of oaked wines with roasted/caramelized and oaked aromas was expected, as oak addition imparts such aromas to wines. In 2017, American-oaked wines had a very strong association with roasted/caramelized and oaked aromas, while French-oaked wines had only a weak association with these aroma categories. This correlation of American-oaked wines with traditional woody characteristics is supported by a study of the impact of American and French oak chip addition on sensory attributes of Syrah wines (Alencar et al. 2019). Oak-aged wines had greater overall aromatic intensity than control wines, and wines produced with American oak chips had more coffee, woody, and sweet/caramelized aromas than French-oaked wines. In a consumer test, wines produced with American oak chips were associated with "woody" characteristics, while wines produced with French oak chips were associated with "vanilla" characteristics. 2018 American- and French-oaked Enchantment wines showed no visible differences in the PCA plot for aroma categories. Overall, these results suggested that oak addition could give Enchantment wines more complex, roasted, and "oaky" aromas than unoaked wines.

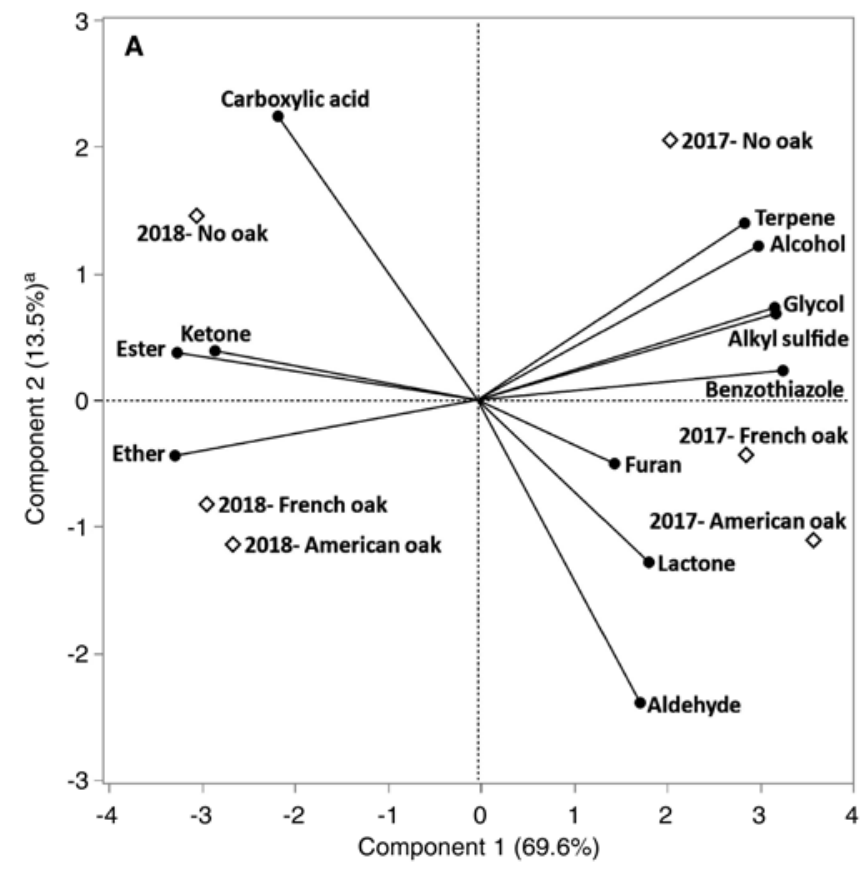

Basic chemistry, anthocyanin, and color attributes during storage (2017). Storage had a major impact on basic chemistry, anthocyanins, and color attributes, while oak was not very influential. In most cases, the impact of storage did not depend on the oak treatment.

Basic chemistry attributes. The storage $\times$ oak interaction was not significant for any basic chemistry attribute but malic acid, and the oak main effect did not impact any attributes (Supplemental Table 3). Storage impacted $\mathrm{pH}$ and TA of Enchantment wine, with $\mathrm{pH}$ increasing from 0 to 12 months storage and TA decreasing from 6 to 12 months storage. However, all $\mathrm{pH}$ and TA values remained within the ranges of $\mathrm{pH} 3.3$ to 3.7 and 0.5 to $0.65 \%$ TA for dry red table wines (Waterhouse et al. 2016). Storage time affected tartaric and citric acids. Tartaric acid concentration decreased from 0 to 6 months storage, consistent with the increased $\mathrm{pH}$. There was no difference among storage times for citric acid concentration.

Anthocyanin attributes. The storage $\times$ oak interaction and oak main effect were not significant for any anthocyanin attributes (Supplemental Table 4). Storage affected all anthocyanin attributes (Figure 4). Individual and total anthocyanin concentrations decreased from 0 to 12 months storage, with the exception of total acylated and total coumaryl anthocyanins, which increased from 0 to 6 months storage and then decreased from 6 to 12 months storage. The malvidin3 -glucoside concentration decreased $64 \%$ and total anthocyanins decreased $61 \%$ over 12 months storage. This was likely due to formation of compounds/adducts from monomeric

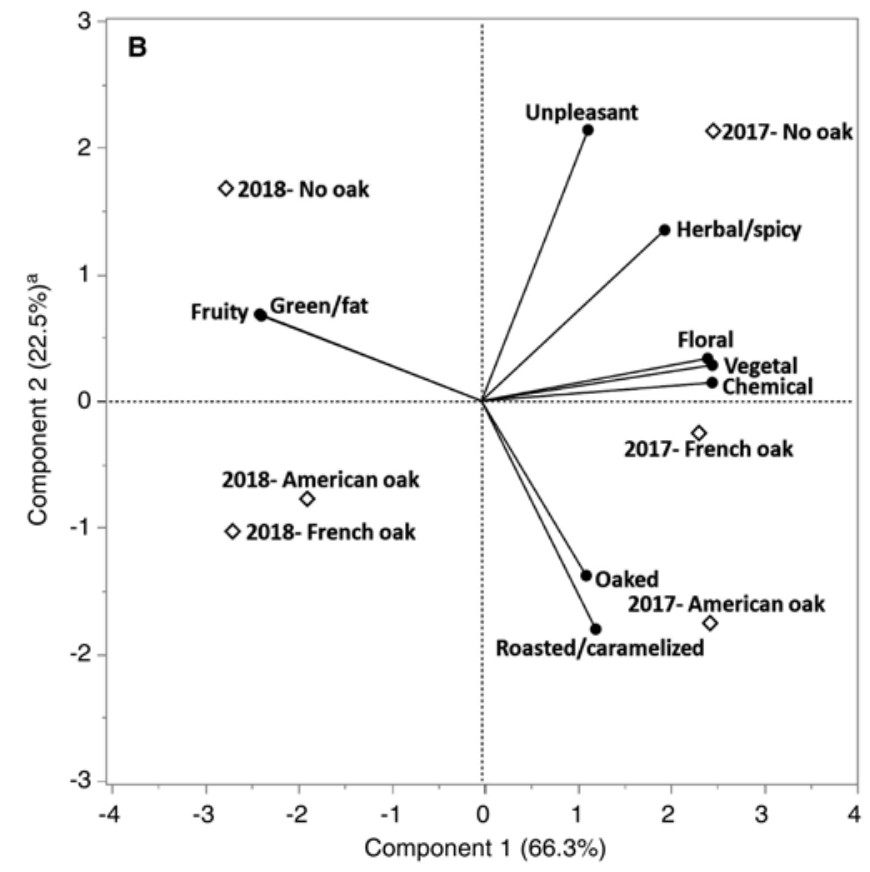

Figure 3 Biplots of principal components analysis on volatile aroma compound classes (A) and aroma categories (B) in wines at 0-months storage at $15^{\circ} \mathrm{C}$ produced from Enchantment grapes grown at the University of Arkansas System Division of Agriculture Fruit Research Station, Clarksville, AR (2017 and 2018). Compound class variables represent the sum of the total ion chromatogram (TIC) relative peak areas (\%) of positively identified compounds within each compound class (Table 3). Aroma category variables represent the sum of the TIC relative peak areas (\%) of positively identified compounds within each aroma category. ${ }^{\text {PPercent }}$ of variation in data explained by each component. 


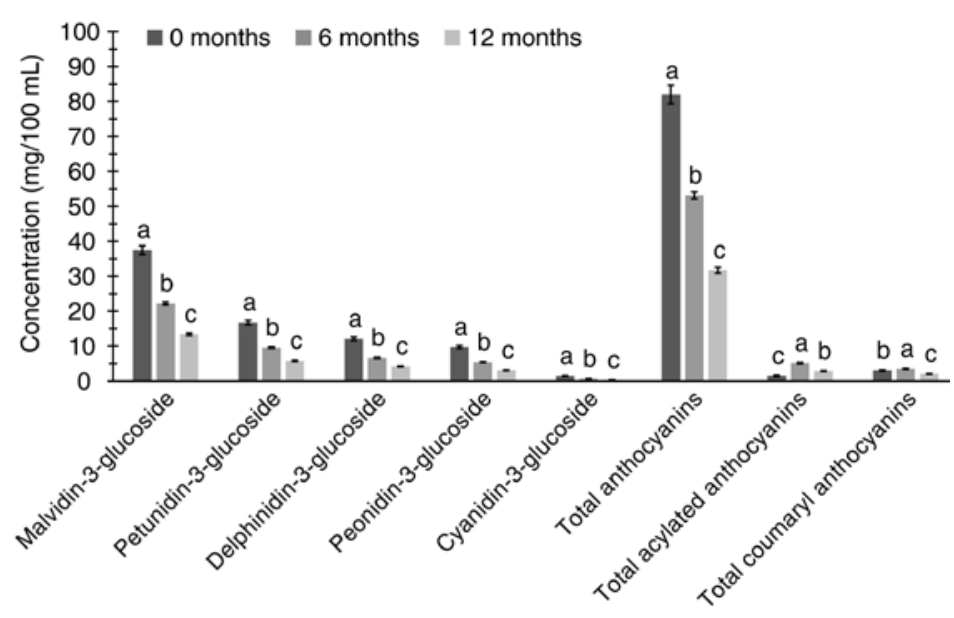

Figure 4 Effect of storage $\left(0,6\right.$, or 12 months at $\left.15^{\circ} \mathrm{C}\right)$ on anthocyanin attributes of wines produced from Enchantment grapes grown at the University of Arkansas System Division of Agriculture Fruit Research Station, Clarksville, AR (2017). Error bars represent standard error. Means with different letters for each attribute are significantly different $(p<0.05)$ according to Tukey's honest significant difference test.
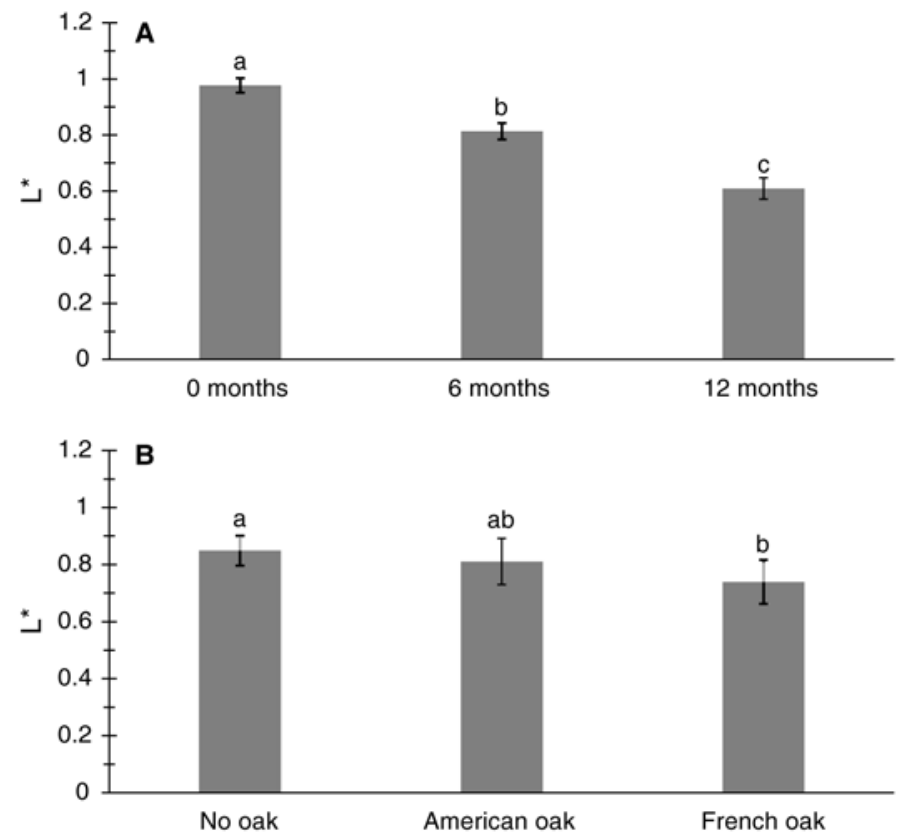

Figure 5 Effect of storage $\left(0,6\right.$, or 12 months at $\left.15^{\circ} \mathrm{C}\right)(\mathbf{A})$ and oak treatment (no oak, American oak, or French oak staves) (B) on $L^{*}$ of wines produced from Enchantment grapes grown at the University of Arkansas System Division of Agriculture Fruit Research Station, Clarksville, AR. Error bars represent standard error. Means with different letters within each effect are significantly different $(p<0.05)$ according to Tukey's honest significant difference test.

anthocyanins that can influence and stabilize wine color during storage (Escribano-Bailón and Santos-Buelga 2012, de Freitas et al. 2017, Li and Duan 2019).

Color attributes. The storage $\times$ oak interaction was not significant for any color attributes except $b^{*}$, but there were no differences among treatments (Supplemental Table 5). Storage affected all color attributes except $b^{*}$. There was no effect of oak treatment on any color attribute except L*. Enchant-

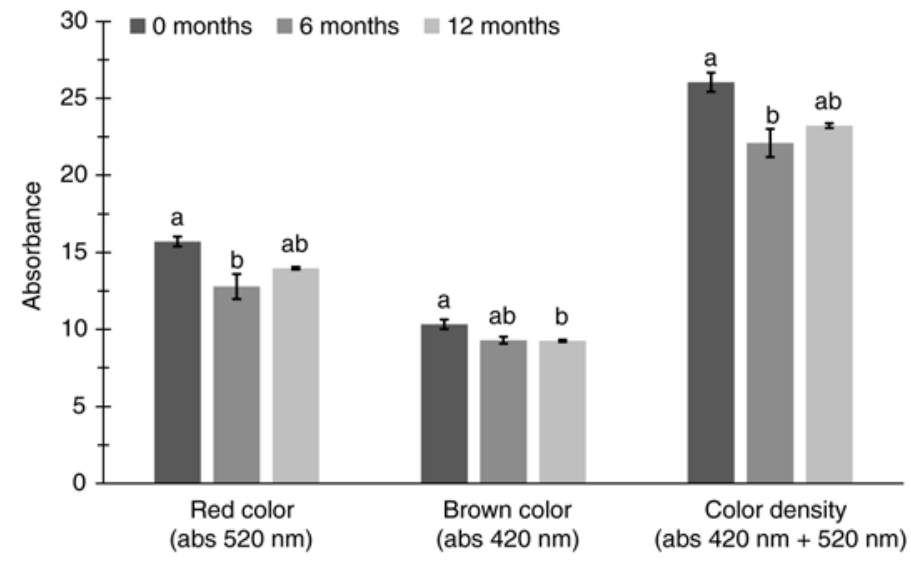

Figure 6 Effect of storage $\left(0,6\right.$, or 12 months at $\left.15^{\circ} \mathrm{C}\right)$ on red color, brown/ yellow color, and color density of wines produced from Enchantment grapes grown at the University of Arkansas System Division of Agriculture Fruit Research Station, Clarksville, AR. Error bars represent standard error. Means with different letters for each attribute are significantly different $(p<0.05)$ according to Tukey's honest significant difference test.

ment wines became darker during storage (decreasing $L^{*}$ ) and French-oaked wines had darker color than unoaked wines (Figure 5). Storage time was significant for $\mathrm{a}^{*}$ : the red color of wines increased (increasing $\mathrm{a}^{*}$ ) from 0 to 12 months storage. The red color and color density of Enchantment wines decreased from 0 to 6 months storage, but had a slight (although insignificant) increase from 6 to 12 months storage (Figure 6). This was in contrast to the $a^{*}$ measurements, which showed red color increasing during storage. Brown/yellow color decreased from 0 to 12 months storage.

\section{Conclusions}

In both 2017 and 2018, Enchantment wines had basic chemistry within acceptable ranges for a dry red table wine, remaining mostly stable during one year of storage at $15^{\circ} \mathrm{C}$. Anthocyanin-3-glucosides, but not their diglucoside counterparts, were identified in Enchantment wines, with malvidin3 -glucoside as the predominant anthocyanin. Although red color and color density decreased slightly during 12 months storage, Enchantment wines maintained a deep red/purple color. There was minimal impact of oak treatment on basic chemistry and anthocyanins, but some impact on color attributes. The volatile aroma profiles of Enchantment wines were clearly distinguished by year and oak treatment: oaked wines in both years were associated with more oaky, roasted, and caramelized aroma compounds. Enchantment can be used to produce high-quality, deeply red-colored wines that benefit from oak additions and retain quality during storage. Enchantment shows potential as a teinturier winegrape for the mid-south United States, as a single varietal or to enhance wine blends.

\section{Literature Cited}

Acree TE and Arn H. 2004. Flavornet and human odor space. Gas chromatography - olfactometry (GCO) of natural products. https:// www.flavornet.org/. 
Adams RP. 2007. Identification of Essential Oil Components by Gas Chromatography/Mass Spectrometry. Allured Publishing Corporation, Carol Stream, IL.

Alencar NMM, Ribeiro TG, Barone B, Barros APA, Marques ATB and Behrens JH. 2019. Sensory profile and check-all-that-apply (cata) as tools for evaluating and characterizing Syrah wines aged with oak chips. Food Res Int 124:156-164.

Alston JM, Fuller KB, Lapsley JT and Soleas G. 2011. Too much of a good thing? Causes and consequences of increases in sugar content of California wine grapes. J Wine Econ 6:135-159.

Cadahía E, Muñoz L, Fernández de Simón B and García-Vallejo MC. 2001. Changes in low molecular weight phenolic compounds in Spanish, French, and American oak woods during natural seasoning and toasting. J Agric Food Chem 49:1790-1798.

Cano-López M, Bautista-Ortín AB, Pardo-Mínguez F, López-Roca JM and Gómez-Plaza E. 2008. Sensory descriptive analysis of a red wine aged with oak chips in stainless steel tanks or used barrels: Effect of the contact time and size of the oak chips. J Food Quality 31:645-660.

Chassaing S et al. 2010. Physicochemical studies of new anthocyanoellagitannin hybrid pigments: About the origin of the influence of oak $C$-glycosidic ellagitannins on wine color. Eur J Org Chem 2010:55-63.

Cheynier V, Dueñas-Paton M, Salas E, Maury C, Souquet JM, SarniManchado P and Fulcrand H. 2006. Structure and properties of wine pigments and tannins. Am J Enol Vitic 57:298-305.

Cho MJ, Howard LR, Prior RL and Clark JR. 2004. Flavonoid glycosides and antioxidant capacity of various blackberry, blueberry and red grape genotypes determined by high-performance liquid chromatography/mass spectrometry. J Sci Food Agric 84:1771-1782.

Clark JR, Moore JN, Morris JR and Threlfall RT. 2018. "Opportunity" and "Enchantment" wine grape for the mid-South of the United States. HortScience 53:1208-1211.

Commission Internationale de l'Eclairage (CIE). 1986. Colorimetry. 2nd Edition, Publication CIE No. 15.2. Commission Internationale de l'Eclairage, Vienna.

Da Conceicao Neta ER, Johanningsmeier SD and McFeeters RF. 2007. The chemistry and physiology of sour taste-A review. J Food Sci 72:R33-R38

de Freitas V, Sousa C, Silva AMS, Santos-Buelga C and Mateus N. 2004. Synthesis of a new catechin-pyrylium derived pigment. Tetrahedron Lett 45:9349-9352.

de Freitas V, Fernandes A, Oliveira J, Teixeira N and Mateus N. 2017. A review of the current knowledge of red wine colour. OENO One 51:11.

del Alamo M, Bernal JL and Gómez-Cordovés C. 2000. Behavior of monosaccharides, phenolic compounds, and color of red wines aged in used oak barrels and in the bottle. J Agric Food Chem 48:4613-4618.

del Alamo Sanza M and Domíngues IN. 2006. Wine aging in bottle from artificial systems (staves and chips) and oak woods: Anthocyanin composition. Anal Chim Acta 563:255-263.

del Álamo Sanza M, Nevares Domínguez I and García Merino S. 2004. Influence of different aging systems and oak woods on aged wine color and anthocyanin composition. Eur Food Res Technol 219:124-132

Eiriz N, Oliveira JFS and Clímaco MC. 2007. Fragmentos de carvalho no estágio de vinhos tintos. Ciência Técnica Vitivinícola 22:63-71.

El-Sayed AM. 2003. The Pherobase: Database of Pheromones and Semiochemicals. https://www.pherobase.com.

Escribano-Bailón MT and Santos-Buelga C. 2012. Anthocyanin copigmentation: evaluation, mechanisms and implications for the colour of red wines. Curr Org Chem 16:715-723

Fowles GWA. 1992. Acids in grapes and wines: A review. J Wine Res 3:25-41.
Fulcrand H, dos Santos PJ, Sarni-Manchado P, Cheynier V and FavreBonvin J. 1996. Structure of new anthocyanin-derived wine pigments. J Chem Soc Perk T 17:735-739.

García-Beneytez E, Cabello F and Revilla E. 2003. Analysis of grape and wine anthocyanins by HPLC-MS. J Agric Food Chem 51:5622-5629.

García-Carpintero AG, Sánchez-Palomo E and Gonzaléz Viñas MA. 2010. Influence of co-winemaking technique in sensory characteristics of new Spanish red wines. Food Qual Prefer 21:705-710.

Gómez-Míguez M and Heredia FJ. 2004. Effect of the maceration technique on the relationships between anthocyanin composition and objective color of Syrah wines. J Agric Food Chem 52:5117-5123.

Gómez-Míguez M, González-Miret ML and Heredia FJ. 2007. Evolution of colour and anthocyanin composition of Syrah wines elaborated with pre-fermentative cold maceration. J Food Eng 79:271-278

Gutiérrez IH, Lorenzo ESP and Espinosa AV. 2005. Phenolic composition and magnitude of copigmentation in young and shortly aged red wines made from the cultivars Cabernet Sauvignon, Cencibel, and Syrah. Food Chem 92:269-283.

He F, Liang NN, Mu L, Pan Q, Wang J, Reeves MJ and Duan CQ. 2012. Anthocyanins and their variation in red wines. II. Anthocyanin derived pigments and their color evolution. Molecules 17:1483-1519.

Iland P, Ewart A and Sitters J. 1993. Techniques for Chemical Analysis and Stability Tests of Grape Juice and Wine. Patrick Iland Wine Promotions, Campbelltown, Australia.

Jindra JA and Gallander JF. 1987. Effect of American and French oak barrels on the phenolic composition and sensory quality of Seyval blanc wines. Am J Enol Vitic 38:133-138.

Jordão AM, Ricardo-da-Silva JM and Laureano O. 2006. Effect of oak constituents and oxygen on the evolution of malvidin-3-glucoside and $(+)$-catechin in model wine. Am J Enol Vitic 57:377-381.

Kliewer WM. 1977. Influence of temperature, solar radiation and nitrogen on coloration and composition of Emperor grapes. Am J Enol Vitic 28:96-103.

Kováts E. 1958. Gas-chromatographische Charakterisierung organischer Verbindungen. Teil 1: Retentionsindices aliphatischer Halogenide, Alkohole, Aldehyde und Ketone. Helv Chim Acta 41:1915-1932.

Kraujalyté V, Leitner E and Venskutonis PR. 2012. Chemical and sensory characterisation of aroma of Viburnum opulus fruits by solid phase microextraction-gas chromatography-olfactometry. Food Chem 132:717-723

Li SY and Duan CQ. 2019. Astringency, bitterness and color changes in dry red wines before and during barrel oak aging: An updated phenolic perspective review. Crit Rev Food Sci Nutr 59:1840-1867.

Li SY, Zhao PR, Ling MQ, Qi MY, García-Estévez I, Escribano-Bailón MT, Chen XJ, Shi Y and Duan CQ. 2020. Blending strategies for wine color modification I: Color improvement by blending wines of different phenolic profiles testified under extreme oxygen exposures. Food Res Int 130:108885.

Liu SQ and Davis CR. 1994. Analysis of wine carbohydrates using capillary gas liquid chromatography. Am J Enol Vitic 45:229-234.

Masson G, Guichard E, Fournier N and Puech J-L. 1995. Stereoisomers of $\beta$-methyl- $\gamma$-octalactone. II. Contents in the wood of French (Quercus robur and Quercus petraea) and American (Quercus alba) oaks. Am J Enol Vitic 46:424-428.

Meredith CP, Bowers JE, Riaz S, Handley V, Bandman EB and Dangl GS. 1999. The identity and parentage of the variety known in California as Petite Sirah. Am J Enol Vitic 50:236-242.

Monagas M, Núñez V, Bartolemé B and Gómez-Cordovés C. 2006a. Phenolic content of blends of Tempranillo with Graciano or Cabernet Sauvignon wines produced in Spain. Food Technol Biotechnol 44:507-513. 
Monagas M, Bartolemé B and Gómez-Cordovés C. 2006b. Effect of the modifier (Graciano vs. Cabernet Sauvignon) on blends of Tempranillo wine during ageing in the bottle. I. Anthocyanins, pyranoanthocyanins and non-anthocyanin phenolics. LWT Food Sci Technol 39:1133-1142.

Mondello L. 2015. Mass spectra of flavors and fragrances of natural and synthetic compounds. 3rd ed. John Wiley \& Sons, Inc., Hoboken, NJ.

Pastrana-Bonilla E, Akoh CC, Sellappan S and Krewer G. 2003. Phenolic content and antioxidant capacity of Muscadine grapes. J Agric Food Chem 51:5497-5503.

Ramey DD and Ough CS. 1980. Volatile ester hydrolysis or formation during storage of model solutions and wines. J Agric Food Chem 28:928-934.

Reisch BI, Owens CL and Cousins PS. 2012. Grape. In Fruit Breeding. ML Badenes and DH Byrne (eds.), pp. 225-262. Springer, New York.

Revilla E, Losada MM and Gutiérrez E. 2016. Phenolic composition and color of single cultivar young red wines made with Mencia and Alicante-Bouschet grapes in AOC Valdeorras (Galicia, NW Spain). Beverages 2:18.

Revilla I and González-SanJosé M. 2001. Effect of different oak woods on aged wine color and anthocyanin composition. Eur Food Res Technol 213:281-285.

Santiago JL, González I, Gago P, Alonso-Villaverde V, Boso S and Martínez MC. 2008. Identification of and relationships among a number of teinturier grapevines that expanded across Europe in the early 20th century. Aust J Grape Wine Res 14:223-229.

Schwarz M, Wabnitz TC and Winterhalter P. 2003. Pathway leading to the formation of anthocyanin-vinylphenol adducts and related pigments in red wines. J Agric Food Chem 51:3682-3687.
Singleton VL. 1995. Maturation of wines and spirits: Comparisons, facts, and hypotheses. Am J Enol Vitic 46:98-115.

Singleton VL and Ough CS. 1962. Complexity of flavor and blending of wines. J Food Sci 27:189-196.

Sousa A, Fernandes A, Mateus N and de Freitas V. 2012. Synthesis and structural characterization of oaklin-catechins. J Agric Food Chem 60:1528-1534.

Sowalsky RA and Noble AC. 1998. Comparison of the effects of concentration, $\mathrm{pH}$ and anion species on astringency and sourness of organic acids. Chem Senses 23:343-349.

Spayd SE, Tarara JM, Mee DL and Ferguson JC. 2002. Separation of sunlight and temperature effects on the composition of Vitis vinifera cv. Merlot berries. Am J Enol Vitic 53:171-182.

Walker T, Morris J, Threlfall R and Main G. 2003. Analysis of wine components in Cynthiana and Syrah wines. J Agric Food Chem 51:1543-1547.

Waterhouse AL, Sacks GL and Jeffery DW. 2016. Understanding Wine Chemistry. John Wiley \& Sons, Ltd, Chichester, UK.

Zhang B, He F, Liu Y, Cai J and Duan CQ. 2017. Impact of adding ellagic acid to red grapes on the phenolic composition and chromatic quality of Cabernet Sauvignon wines from a warm climate. J Food Process Pres 41:1-11.

Zhu L, Zhang Y, Deng J, Li H and Lu J. 2012. Phenolic concentrations and antioxidant properties of wines made from North American grapes grown in China. Molecules 17:3304-3323. 